\title{
The impacts of biofertilizer and mineral fertilization on the growth and production of yellow passion fruit irrigated with moderately saline water
}

\author{
José A. M. do Nascimento', Lourival F. Cavalcante'2, Ítalo H. L. Cavalcante', \\ Walter E. Pereira ${ }^{2}$, Stênio A. G. Dantas ${ }^{4}$, and Sherly A. da S. Medeiros ${ }^{5}$ \\ ${ }^{1}$ Federal Institute of Education, Science and Technology of Ceará, Campus Tianguá, Highway CE 187, CEP: \\ 62320-000. Tianguá -Ceará, Brazil. \\ ${ }^{2}$ University Federal of Paraíba, Campus II, Highway PB 079 - Km 12, CEP: 58397-000. Areia, Paraíba, Brazil. \\ ${ }^{3}$ University Federal of Vale do São Francisco, Highway BR 407 - km 12, CEP: 56300990. Petrolina, \\ Pernambuco, Brazil. \\ ${ }^{4}$ Post Graduate Program of Plant Science, Plant Science Department, University Campus, CEP: 36.570-000. \\ Viçosa, Minas Gerais, Brazil. \\ ${ }^{5}$ Post Graduate Program in Agronomy, University Federal of Paraíba, Campus II, Highway PB 079 - Km 12,
} CEP: 58397-000. Areia, Paraíba, Brazil.

\begin{abstract}
J.A.M. Nascimento, L.F.Cavalcante, Í.H.L. Cavalcante, W.E. Pereira, S.A.G. Dantas, and S.A.S. Medeiros. 2016. The impacts of biofertilizer and mineral fertilization on the growth and production of yellow passion fruit irrigated with moderately saline water. Cien. Inv. Agr. 43(2):253-262. Yellow passion fruit, because it is sensitive to the salinity of irrigation water or soil, requires restrictive water management strategies and inputs that mitigate the effects of salts on plants irrigated with harmful saline water levels. As such, an experiment was designed to evaluate the effects of bovine biofertilizer and mineral fertilization with NPK on the growth and production of yellow passion fruit plants irrigated with moderately saline water. Treatments were arranged in a randomized block with three replications and 12 plants per plot using a $4 \times 2$ factorial design with four doses of bovine biofertilizer diluted in water at $0,33.3,66.6$ and $100 \%$ proportions in soil with and without NPK. The evaluated variables included the stem diameter, number of productive branches at the beginning of flowering (160 days after transplanting seedlings), number of fruits per hectare, average fruit weight and productivity. Biofertilizer applied at the maximum dose combined with mineral fertilization with NPK resulted in a greater growth in the stem diameter and an increased plant productivity. The $100 \%$ biofertilizer dose provided the best results. Even in treatments without mineral fertilizer, the biofertilizer increased productivity to values approaching $24 \mathrm{tha}^{-1}$ at the $60.65 \%$ level.
\end{abstract}

Key words: Organic input, salinity, Passiflora edulis Sims.

\section{Introduction}

Yellow passion fruit plants grow, develop and produce fruits under tropical and subtropical climates.

Received September 8, 2015. Accepted June 24, 2016. Corresponding author: adeilson.nascimento@ifce.edu.br
Therefore, this plant contributes to the expansion of cultivated area in Brazil, mainly in the Southeast and Northeast (IBGE, 2013). Yellow passion fruit culture is of great importance to national and international agribusinesses. It stimulates the generation of foreign exchange and jobs due 
to appreciation of the fruit, its physicochemical properties and pharmacotherapeutic effects of its juice (Silva et al., 2015). However, the feasibility of its growth in semi-arid areas of the Northeast depends on irrigation, which is performed, in large part, with a saline water content detrimental to the growth, production and quality of fruits (Soares et al., 2008; Dias et al., 2011; Viana et al., 2012).

High levels of salts in irrigation water, soil or both undermine the growth and production of commercially valuable glycophyte plants in at least three aspects: these factors (a) limit the availability of water and nutrients by reducing the matric potential and osmotic soil solution; (b) cause nutritional, physiological and biochemical imbalance in plants; and (c) induce specific toxicity of ions such as $\mathrm{Na}^{+}$and $\mathrm{Cl}^{-}$by mixing salts in irrigation water or soil solutions (Hamdia and Shaddad, 2010). In this context, the conventional cultivation of yellow passion fruit, because of its salt sensitivity, requires the use of irrigation management practices that mitigate the use of water with high salt levels.

Prior research has shown that biofertilizers produced from the fermentation of fresh cattle manure and water exert positive effects in reducing damage caused by water and soil salinity to the growth and production of yellow passion fruit (Cavalcante et al., 2009). Bovine biofertilizer, because it is a source of fermented organic matter, may stimulate the release of humic substances when applied to the soil and cause an increase in the production of organic solutes such as sugars, total free amino acids, proline and glycine betaine, which positively affects nutrition and increases the ability of plants to make osmotic adjustments to salt (Asik et al., 2009; Khaled and Fawy, 2011).

Other beneficial properties of humic substances include the increase of absorption and efficiency of water use by plants, which consequently results in a higher nutrient uptake and greater expansion and cell division (Eyheraguibel et al., 2008; Turan et al., 2011). Mahdi et al. (2010) suggested that a major positive indirect influence of humic substances on plants is due to their ability to increase solubility and availability of nutrients in the soil (mainly of $\mathrm{P}$ and micronutrients), thereby favoring uptake by plants.

In addition to providing organic matter to the soil, another factor to be considered for plants under salt stress is the supply of nutrients through mineral fertilizers. According to Dias and Blanco (2010), the application of fertilizers to soil does not result in increased plant tolerance to salinity. However, well-nourished plants are less affected by excess salts than plants that are deficient in nutrients. Therefore, an effective soil management and fertilization program is important to allow for living with salinity.

In irrigated crops, bovine biofertilizer improves the soil fertility and growth of yellow passion fruit plants (Campos et al., 2008). However, it has a higher efficiency when applied simultaneously with synthetic mineral fertilizers. According to Rodrigues et al. (2009), the application of biofertilizers in soil with mineral fertilizer provides higher growth and emergence of productive branches, increases productivity and improves physical and chemical qualities of yellow passion fruits.

Despite the beneficial attributes of biofertilizers, scientific information on the effects of bovine biofertilizer on the development and production of fruit plants irrigated with saline water, including the yellow passion fruit, are still scarce in the literature. Considering the economic importance of passion fruit in areas with shortages of quality water, obtaining scientific information on the effects on growth and crop production of water irrigation with saline water, as well as adopting practices that mitigate the negative effects of excessive salts to plants, becomes necessary.

The objective of this study was to evaluate the effects of bovine biofertilizer and mineral fertilizer on the growth and production of yellow passion fruit plants irrigated with moderately saline water. 


\section{Materials and methods}

The experiment was conducted from October 2012 to November 2013 in the municipality of Jaçanã - Rio Grande do Norte, Plateau of the Serra de Cuité in the Trairí region, Brazil $\left(6^{\circ} 25^{\prime} 28.8^{\prime}\right.$ 'S and $36^{\circ} 12^{\prime} 28.8^{\prime}$ 'W). The climate, according to Köppen, is As', hot and dry. Rainfall is concentrated from March to July, and the annual precipitation values for the two years in the cultivation area were 271.4 and $532.0 \mathrm{~mm}$.

According to the Brazilian System of Soil Classification criteria (EMBRAPA, 2013), the soil of the experimental area is classified as Eutrophic RED YELLOW LATOSOL, with a sandy loam texture. Before the application of the treatments, ten simple samples were collected in the $0-40 \mathrm{~cm}$ layer and transformed into a composite sample for physical and chemical characterization regarding fertility (EMBRAPA, 2011) and salinity (Richards, 1954).

A physical characteristic analysis of the soil samples revealed the following values: sand, silt, clay and clay dispersed in water, 720, 172, 108 and $50 \mathrm{~g} \mathrm{~kg}^{-1}$, respectively; the soil density was $1.30 \mathrm{~kg} \mathrm{dm}^{-3}$, the particle density was 2.66 $\mathrm{kg} \mathrm{dm}^{-3}$, the total porosity was $0.51 \mathrm{~m}^{3} \mathrm{~m}^{-3}$, the flocculation was $46.3 \%$, the dispersion level was $53.7 \%$, and the mass moisture with regard to the level of field capacity (-0.33 MPa), permanent wilting point (-1.50 MPa) and available water was 130, 63 and $67 \mathrm{~g} \mathrm{~kg}^{-1}$, respectively. The values relating to fertility included the following: $\mathrm{pH}=$ 6.56; $\mathrm{P}=10 \mathrm{mg} \mathrm{dm}{ }^{-3} ; \mathrm{K}^{+}=110.11 \mathrm{mg} \mathrm{dm}^{-3} ; \mathrm{Ca}^{2+}$ $=2.40 ; \mathrm{Mg}^{2+}=1.47 ; \mathrm{Na}^{+}=0.20 ;$ base sum $-\mathrm{BS}=$
4.35; $\mathrm{H}^{+}+\mathrm{Al}^{3+}=1.23 ; \mathrm{Al}^{3+}=0.0$; cation exchange capacity - $\mathrm{CEC}=5.58 \mathrm{cmol}_{\mathrm{c}} \mathrm{dm}^{-3}$; percentage of base saturation - $\mathrm{V}=77.96 \%$; and organic matter $=8.01 \mathrm{~g} \mathrm{~kg}^{-1}$. Regarding salinity, the soil was not saline and not sodic according to the electrical conductivity of the saturation extract $-\mathrm{ECse}=0.75$ $\mathrm{dS} \mathrm{m}{ }^{-1}$, and the exchangeable sodium percentage $\left[\mathrm{ESP}=100 \times\left(\mathrm{Na}^{+} / \mathrm{CEC}\right)\right]$ was $3.58 \%$.

The treatments were distributed in a randomized block design with three replicates and 12 plants per parcel using a $4 \times 2$ factorial scheme relative to four bovine biofertilizer levels diluted in average water salinity, in soil both with and without NPK mineral fertilizer. The biofertilizer was diluted in irrigation water at $0.0,33.3$. 66.6, and $100.0 \%$ and was provided manually 30 days before and every 60 days after transplanting seedlings until the end of the experiment. The suggestion of 15 $\mathrm{L} \mathrm{m}^{-2}$ (Dias et al., 2011) was adopted and applied at a constant volume of $6 \mathrm{~L}_{\text {plant }}^{-1}$ in a $0.8 \mathrm{~m}^{2}$ area, corresponding to the area of the planting holes. Each bio-fertilizer level was prepared in $3 \mathrm{~m}^{3}$ containers and then sent to the laboratory to be analyzed chemically as if it was water for irrigation (Table 1).

Planting holes were opened to $0.4 \times 0.4 \times 0.4$ $\mathrm{m}$, with $3 \mathrm{~m}$ between plants and $2.5 \mathrm{~m}$ between planting rows and were prepared with 7.5 g plant $^{-1}$ of $\mathrm{P}_{2} \mathrm{O}_{5}$ and $10 \mathrm{~L}$ of bovine manure. The bovine manure has an 18:1 $\mathrm{C} / \mathrm{N}$ ratio and a chemical composition as follows: $\mathrm{pH}=8.81 ; \mathrm{P}_{2} \mathrm{O}_{5}=4.92$; $\mathrm{K}_{2} \mathrm{O}=8.76 ; \mathrm{Na}_{2} \mathrm{O}=1.35 ; \mathrm{cmol}_{\mathrm{c}} \mathrm{dm}^{-3} ; \mathrm{H}^{+}+\mathrm{Al}^{3+}$ $=1.65 \mathrm{cmol}_{\mathrm{c}} \mathrm{dm}^{-3} ; \mathrm{Al}^{3+}=0.0 \mathrm{cmol}_{\mathrm{c}} \mathrm{dm}^{-3} ; \mathrm{CaO}$ $=10.92 ; \mathrm{MgO}=15.87 \mathrm{cmol}_{\mathrm{c}} \mathrm{dm}^{-3} ;$ TOC $=227.64$ $\mathrm{g} \mathrm{kg}^{-1}$ and $\mathrm{N}=12.65 \mathrm{~g} \mathrm{~kg}^{-1}$.

Table 1. Average values of cations, anions, $\mathrm{pH}$ and electrical conductivity of irrigation water and of mixtures of bovine biofertilizer in water used for the experimental period.

\begin{tabular}{|c|c|c|c|c|c|c|c|c|c|c|}
\hline \multirow[b]{2}{*}{ Biofertilizer (\%) } & $\mathrm{Ca}^{2+}$ & $\mathrm{Mg}^{2+}$ & $\mathrm{Na}^{+}$ & $\mathrm{K}^{+}$ & $\mathrm{SO}_{4}^{-2}$ & $\mathrm{CO}$ & $\mathrm{HCO}_{3}^{-2}$ & $\mathrm{Cl}^{-}$ & \multirow[b]{2}{*}{$\mathrm{pH}$} & \multirow{2}{*}{$\begin{array}{c}\mathrm{EC} \\
\left(\mathrm{dS} \mathrm{m}^{-1}\right)\end{array}$} \\
\hline & \multicolumn{8}{|c|}{$\mathrm{mmol}_{\mathrm{c}} \mathrm{L}^{-1}$} & & \\
\hline 0.0 (water) $^{1}$ & 2.60 & 5.40 & 28.5 & 1.01 & 0.30 & 0.00 & 2.20 & 34.96 & 4.52 & 3.77 \\
\hline 33.3 & 9.58 & 10.57 & 8.30 & 8.38 & 5.64 & 0.00 & 2.40 & 23.21 & 5.86 & 0.80 \\
\hline 66.6 & 11.36 & 13.15 & 9.90 & 9.66 & 10.62 & 0.00 & 4.64 & 30.35 & 6.08 & 4.54 \\
\hline 100.00 & 14.59 & 14.72 & 10.67 & 16.23 & 20.26 & 0.00 & 6.79 & 32.49 & 6.10 & 5.15 \\
\hline
\end{tabular}

${ }^{1}$ The level $0.0 \%$ biofertilizer corresponds to application of only water. 
Transplantation was performed at the end of October 2012 in the dry period using $18 \mathrm{~cm}$ high seedlings with $5 \mathrm{~mm}$ diameter stems. Planting was conducted as single stems in vertical cordons with wire no. 12 installed on the top of the pole at 2.20 $\mathrm{m}$ height. The top-dressing mineral fertilization was made with NPK from urea $(45 \% \mathrm{~N})$, simple superphosphate $\left(20 \% \mathrm{P}_{2} \mathrm{O}_{5} ; 20 \% \mathrm{Ca}^{2+}, 12 \% \mathrm{~S}\right)$ and potassium chloride $\left(58 \% \mathrm{~K}_{2} \mathrm{O}\right)$.

Nitrogen fertilization was performed at 30 days after transplanting (DAT) using 4.5 g plant $^{-1}$, at 60 and 90 DAT with $10 \mathrm{~g} \mathrm{plant}^{-1}$, and from 120 DAT until the last application in September 2013 with 20 g plant $^{-1}$ of $\mathrm{N}$. Potassium fertilization consisted of 4.5 and 26.3 g plant $^{-1}$ of $\mathrm{K}_{2} \mathrm{O}$ applied together with the first nitrogen fertilization in the beginning of flowering and 90 days thereafter, respectively. Phosphorus fertilization with $22.5 \mathrm{~g}$ plant ${ }^{-1}$ of $\mathrm{P}_{2} \mathrm{O}_{5}$ was performed in flowering plants simultaneously with potassium.

Irrigation of plants was based on crop evapotranspiration (ETc) obtained by multiplication of ETo (potential evapotranspiration) by the crop coefficient $(\mathrm{kc})$. The potential evapotranspiration was estimated by the multiplication of a class 'A' evaporation pan installed near the experiment by a factor of 0.75 . The kc values adopted were $0.69,1.13$ and 1.08 , as obtained by Souza et al. (2009) for yellow passion fruit in Vale do Curu, Pentecoste, a semi-arid region of Ceará, relative to the first 90 DAT, flowering and fruiting from 90 to 150 DAT, and during ripening from 150 to the end of the culture, respectively. The water was evaluated monthly for salt content (Table 2). The irrigation was performed by dripping using two Katif drippers
(Plastro Brasil ${ }^{\circledR}$, Uberlândia, Minas Gerais, Brazil) at a flow rate of $3.75 \mathrm{~L} \mathrm{~h}^{-1}$ installed 20 $\mathrm{cm}$ from the stem.

At 30, 60, 90, 120, 150, 180, 210 and 240 DAT, the stem diameter was measured with a digital caliper $10 \mathrm{~cm}$ above the collar. At 130 DAT, the beginning of flowering, the productive branches were counted. The harvest began in March 2013, and fruits were harvested daily with at least 20\% of the area yellowing (Rodrigues et al., 2009), packed in type " $\mathrm{K}$ " boxes and counted. Number of fruits per plant, average mass of fruits and productivity were also obtained.

Data were submitted to an analysis of variance. Means related to mineral fertilizer were compared by $\mathrm{F}$ test and those related to biofertilizer by regression were compared using the software SAS (SAS Institute Inc., Cary, NC, USA).

\section{Results and discussion}

The stem diameter increased significantly and linearly from 30 to 240 DAT and responded to applied biofertilizer levels (Figure 1). According to Figure 1A, the average diameter of plants grew $0.0859 \mathrm{~mm}$ day $^{-1}$ and $2.5771 \mathrm{~mm}$ per 30 -day interval. At the last evaluation (240 days), they were $20.3 \mathrm{~mm}$. Linear growth means that, at the end of the evaluation, plants maintained stem diameter growth, despite having already entered the flowering stage. Rodolfo Júnior et al. (2008) recorded $25 \mathrm{~mm}$ in passion fruit plants at 210 days after transplanting in soil with biofertilizer and mineral fertilizer irrigated with non-saline water $\left(0.50 \mathrm{dS} \mathrm{m}^{-1}\right)$.

Table 2. Monthly values of $\mathrm{pH}$ and electrical conductivity of the saline water used for irrigation.

\begin{tabular}{|c|c|c|c|c|c|c|c|c|c|c|c|c|c|c|}
\hline \multirow[b]{2}{*}{ Variables } & \multicolumn{3}{|c|}{2012} & \multicolumn{11}{|c|}{2013} \\
\hline & Oct. & Nov. & Dec. & Jan. & Feb. & Mar. & Apr. & May & June & July & Aug. & Sept. & Oct. & Nov. \\
\hline $\mathrm{pH}$ & 4.05 & 4.04 & 5.70 & 4.20 & 3.88 & 4.21 & 4.66 & 4.01 & 4.49 & 4.49 & 3.98 & 3.90 & 3.83 & 3.83 \\
\hline $\mathrm{EC}\left(\mathrm{dS} \mathrm{m}^{-1}\right)$ & 3.68 & 3.74 & 3.81 & 3.83 & 4.91 & 3.88 & 4.12 & 3.76 & 4.65 & 4.49 & 4.03 & 3.98 & 3.84 & 3.90 \\
\hline
\end{tabular}



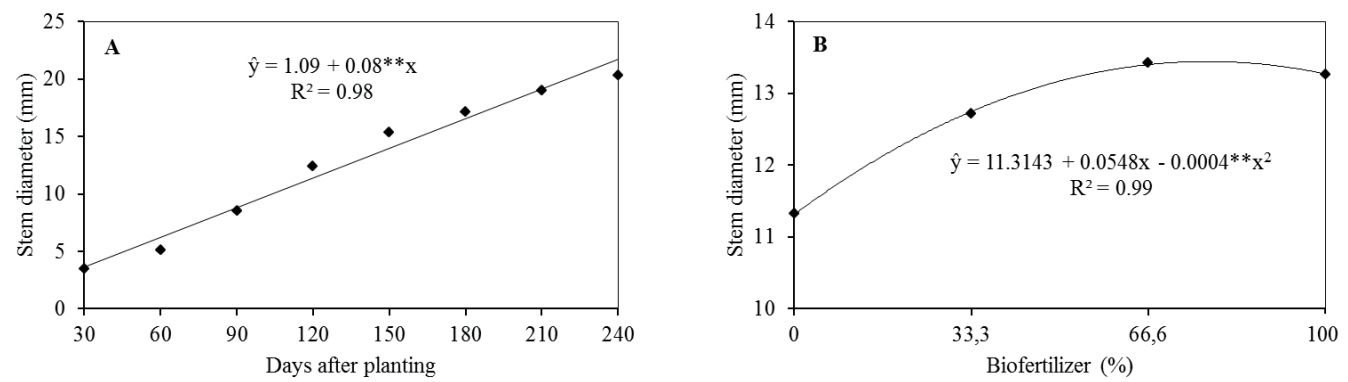

Figure 1. Average stem diameter of yellow passion fruit according to the age of plants (A) and levels of bovine biofertilizer (B) at 240 DAT in crops irrigated with saline water, in soil with and without NPK mineral fertilizer.

Regarding biofertilizer levels (Figure 1B), the stem diameter at 240 days increased to a maximum of $13.45 \mathrm{~mm}$ in relation to the $78.2 \%$ estimated maximum dose of biofertilizers. The increase in stem growth in plants, according to Eyheraguibel et al. (2008) and Khaled and Fawi (2011), is a response of humic substances in the biofertilizer providing a higher absorption of water and nutrients to plants, which stimulates growth and cell division.

Additionally, the organic feedstock promotes physical improvement of the soil by increasing pore spaces to root growth and via water and nutrient dynamics. The value of 13.45 is less than the $23.63 \mathrm{~mm}$ obtained by Diniz et al. (2011) with yellow passion fruit at 330 DAT grown in soil with bovine biofertilizer, mineral fertilizer and irrigated with non-saline water $\left(0.25 \mathrm{dS} \mathrm{m}^{-1}\right)$. It is similar, however, to the $13 \mathrm{~mm}$ obtained by Cavalcante et al. (2007b) at 210 DAT for yellow passion fruit plants with increasing levels of common biofertilizer in low fertility soil irrigated with non-saline water $\left(0.42 \mathrm{dS} \mathrm{m}^{-1}\right)$.

The lower results compared to those observed by authors who did not use saline water (Rodolfo Júnior et al., 2008; Diniz et al., 2011) may be an indication that the plant initially suffered from the stress caused by excess salts, although plants exhibited linear growth during the evaluated period. Hamdia and Shaddad (2010) reported that the intensity of damage to plants by an excess of salts varies with the growth stage of plants. The initial phases are the most affected due to a greater need for water absorption for expansion and cell division, which also increases the absorption of salts. In these phases, plants do not have defense systems against fully developed stresses.

The number of branches in the early fruiting stage at DAT 160 was significantly influenced by the interaction of biofertilizer $\times$ mineral fertilizer - NPK (Figure 2A). In soil without NPK, the increase of the liquid organic compound inhibited the emission of productive branches from 29.7 to 25.3, 22.5 and 21.5 branches plant $^{-1}$, averaging 24.8 branches plant ${ }^{-1}$. In soil with mineral fertilizer, despite not fitting any mathematical model, the average value of 25.3 branches plant $^{-1}$ exceeds the average of plants without mineral fertilization. Cavalcante et al. (2007a) did not detect significant differences in the number of productive branches of yellow passion fruit plants irrigated with saline water from 0.5 to $2.5 \mathrm{dS} \mathrm{m}^{-1}$ and organic matter in the form of bovine manure.

Rodolfo Júnior et al. (2008) also found no significant effects for biofertilizer levels and mineral fertilization on the number of productive branches of yellow passion fruit at 160 days after transplanting while irrigating with non-saline water, but reported a similar average of 24.7 branches plant $^{-1}$. These values are lower than the average 34 branches plant $^{-1}$ obtained by Cavalcante et al. (2007b) with plants treated with biofertilizer at 
180 days after transplanting which were irrigated with non-saline water.

The number of fruits per hectare (NFH) in treatments with mineral fertilizer increased with increasing biofertilizer levels applied to the soil. The maximum value of $133,442.3$ ha fruit $^{-1}$ corresponded to $85.74 \%$ biofertilizer levels (Figure 2B). In the treatments without mineral fertilization, there was no adjustment of the data to any regression model and was thus represented by the 106,005 hectare fruit $^{-1}$ average value. The number of fruits was higher in treatments with the presence of mineral fertilizer, especially when higher levels of organic input were applied. It exceeded the 46,828 fruits ha-1 value obtained by Soares et al. (2008) for passion fruit irrigated with saline water with a $4.0 \mathrm{dS} \mathrm{m}^{-1}$ electrical conductivity and the 56,839 fruits ha ${ }^{-1}$ value obtained by Dias et al. (2011) for passion fruit in soil treated with biofertilizer and irrigated with saline water with an ECa of $4.5 \mathrm{dS} \mathrm{m}^{-1}$.

These results also exceed the 69,972 fruit ha $^{-1}$ value obtained by Cavalcante et al. (2007b) for passion fruit plants grown in soil with biofertilizer and irrigated with non-saline water but are lower than the $153,849.64$ fruits ha $^{-1}$ recorded by Rodolfo Junior et al. (2008) for passion fruit in soil treated with common biofertilizer and the 144,333 fruits ha ${ }^{-1}$ obtained by Rodrigues et al. (2009) for passion fruit grown in soil with biofertilizer and mineral fertilizer. Our results showed that, just

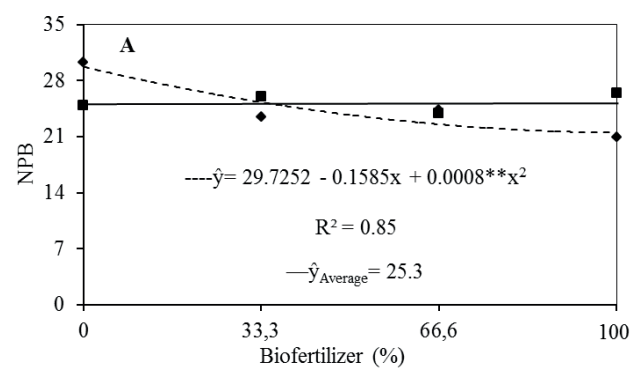

as with the number of branches per plant, NFH reached higher values in treatments with the presence of mineral fertilizer, especially when applied with the highest levels of biofertilizer, which indicates that there was a direct relation between the increase in the number of fruits and the number of productive branches.

The average fruit weight (AFW) increased linearly from $199.17 \mathrm{~g}$ to $239.72 \mathrm{~g}$ with the increase in biofertilizer levels in treatments with mineral fertilizer (Figure 3A). There was an increase of 0.4 $\mathrm{g}$ for every unit increase in applied biofertilizer levels and a gain of $20.3 \%$ in average weight of fruits harvested from plants with $100 \%$ biofertilizer treatments relative to the $0 \%$ level. This increase is a response to a better physical and chemical conditioning of the soil caused by higher levels of biofertilizer and the beneficial effects provided by humic substances to plants, which favors higher osmotic adjustment, nutrient uptake, increased production of sugars and increased efficiency of water use (Eyheraguibel et al., 2008; Asik et al., 2009; Turan et al., 2011).

AFW values for the treatments without mineral fertilizer, similar to NFH, did not adjust to any polynomial regression model and were represented by the average value of $210 \mathrm{~g}$. Both with and without mineral fertilizer, the values surpass the $133 \mathrm{~g}^{\text {fruit }^{-1}}$ obtained by Soares et al. (2008) for passion fruit irrigated with saline water up to $4.0 \mathrm{dS} \mathrm{m}^{-1}$ as well as the $132.1 \mathrm{~g}$ fruit $^{-1}$ observed

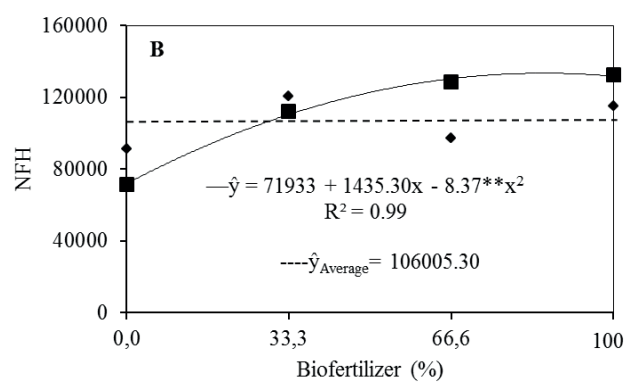

Figure 2. Number of productive branches (A) and per-hectare fruits of yellow passion fruit (B) at 160 DAT irrigated with saline water $\left(3.89 \mathrm{dS} \mathrm{m}^{-1}\right)$ according to bovine biofertilizer doses in the soil (---) and with (-) NPK fertilization. 
by Dias et al. (2011) with yellow passion fruit grown in soil irrigated with saline water with an EC of $4.5 \mathrm{dS} \mathrm{m}^{-1}$ and treated with biofertilizer. This value was also higher than those obtained by Choi et al. (2007a), Rodolfo Júnior et al. (2008) and Rodrigues et al. (2009) with passion fruit plants treated with biofertilizer and mineral fertilization under irrigation with non-saline water.

Similar to the number of fruits, the mass recorded for fruits obtained from plants treated with mineral fertilizer were higher than those obtained from untreated plants. This indicates that the increasing levels of biofertilizer in soil with mineral fertilization not only increased the number of fruits but also increased their mass.

A fruit weight considered adequate for the in natura fruit market in São Paulo is between 170 and 210 $\mathrm{g}$, while over $150 \mathrm{~g}$ was reported in the Northeast by Rodrigues et al. (2009). This indicates that, even in treatments without NPK, fruits reached mass values suitable for the market and that biofertilizer possibly reduced the negative effects of salinity of irrigation water on fruit weight. This may be the case because water salinity reduces the average weight of fruits of plants not treated with organic matter, as verified by Freire et al. (2010), who recorded values below $170 \mathrm{~g}$.

In soil with mineral fertilization, the increase in levels of biofertilizer linearly increased productivity from 15.91 to $32.1 \mathrm{t} \mathrm{ha}^{-1}$, which means that the highest level of biofertilizer (100\%) afforded a more than $100 \%$ increase in productivity compared to treatments without biofertilizer $(0.0 \%)$ (Figure 3B). The application of organic inputs to the soil enhances and increases the positive effects exerted by the mineral fertilizer. It also reduces the loss of soil nutrients by chemically and physically conditioning the soil through the action of humic substances (Turan et al., 2011).

According to Dias and Blanco (2010), the mineral fertilizer subjected to salt stress in plants is extremely important because, although this does not increase the tolerance of plants to salinity, it provides a greater ability to withstand the negative effects of excess of salts in the soil.

In soil without mineral fertilizer, productivity was increased up to a maximum of $23.97 \mathrm{tha}^{-1}$ for $60.65 \%$ biofertilizer. These results are significantly higher than $1.62 \mathrm{t} \mathrm{ha}^{-1}$, which was obtained by Cavalcante et al. (2007a) for passion fruit plants irrigated with saline water $\left(\mathrm{EC}=2.5 \mathrm{dS} \mathrm{m}^{-1}\right)$ and organic matter in the planting hole and are also higher than the value of $6 \mathrm{t} \mathrm{ha}^{-1}$ obtained by Soares et al. (2008) with passion fruit plants irrigated with saline water $\left(\mathrm{EC}=4.0 \mathrm{dS} \mathrm{m}^{-1}\right)$ and the $7.5 \mathrm{t}$ ha $^{-1}$ value found by Dias et al. (2011) with passion fruit plants irrigated with saline water $(\mathrm{ECa}=4.5$ $\mathrm{dS} \mathrm{m}^{-1}$ ) in soil with biofertilizer.

In plants grown in soil treated with biofertilizer and mineral fertilization under irrigation with

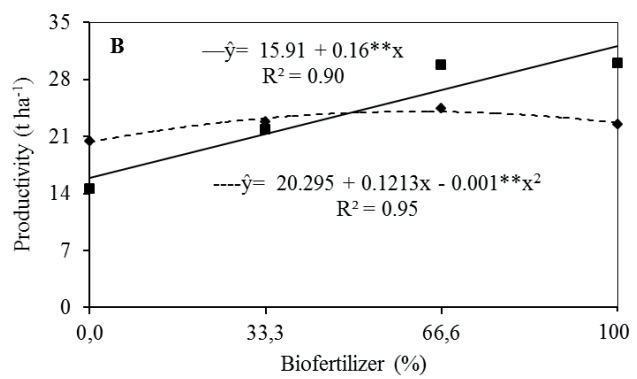

Figure 3. Average fruit weight (A) and per-hectare productivity (B) of yellow passion fruit treated with biofertilizer in soil without (---) and with (-) NPK fertilization. 
non-saline water, Cavalcante et al. (2007b) recovered a productivity of $13.7 \mathrm{t} \mathrm{ha}^{-1}$; Rodolfo Júnior et al. (2008) recorded $41.1 \mathrm{t} \mathrm{ha}^{-1}$; and Rodrigues et al. (2009) obtained $26.11 \mathrm{t} \mathrm{ha}^{-1}$. Except for the data observed by Rodolfo Júnior et al. (2008), productivity data obtained in this study surpass the data referenced by the other mentioned experiments, indicating that the biofertilizer had a positive action on the soil and plants by reducing the negative effects of excess of irrigation water salts and stimulating the production of fruits.

Considering that the national average production is $14.3 \mathrm{tha}^{-1}$ and that production in the Northeast is $13.9 \mathrm{t} \mathrm{ha}^{-1}$ (IBGE, 2013), the values obtained in this work are markedly higher. In the region where this study was conducted, the average productivity is currently approximately $16 \mathrm{tha}^{-1}$, which means that even the isolated application of biofertilizer (soil without mineral fertilizer) was able to increase crop production by $80 \%$ over just irrigation with saline water. This indicates that plants treated without mineral fertilizer also reached a sufficient nutritional status to express satisfactory production. This can be confirmed by the fact that the manure applied in the preparation of the planting hole was rich in certain macronutrients. Furthermore, the application of biofertilizer every 60 days helped to supply nutrients to the culture.

Biofertilizers produced from organic waste, in addition to contributing nutrients, albeit in small quantities, also increase the solubility of $\mathrm{P}$ compounds and micronutrients already existing in the soil, which increases their availability for plants (Mahdi et al., 2010). However, the increase in productivity with the increase of biofertilizer levels are largely due to the positive effects of humic substances from the organic input on physical, chemical and biological characteristics of the soil by improving growing conditions of the root system and therefore increasing water and nutrient uptake by plants. According to Eyheraguibel et al. (2008) and Asik et al. (2009), the application of humic substances from organic residues in soil affected by salts may induce an increased osmotic adjustment in plants through the accumulation of organic solutes, promoting a greater absorption of water and nutrients.

The application of biofertilizer to the soil increases growth and production of yellow passion fruit. The increase was higher in plants treated with mineral fertilizer. The largest dose of biofertilizer (100\%) provided the greatest productivity $\left(\mathrm{t} \mathrm{ha} \mathrm{h}^{-1}\right)$. Even in the absence of mineral fertilizer, biofertilizer increases productivity to values approaching 24 $\mathrm{t} \mathrm{ha}^{-1}$ at the $60.65 \%$ dose, which corresponds to an $80 \%$ increase over the average productivity of the region (approximately $16 \mathrm{tha}^{-1}$ ). Biofertilizer exerted a positive action by alleviating the negative effects caused by excess irrigation water salinity, considering that plants were irrigated with saline water above $3.6 \mathrm{dS} \mathrm{m}^{-1}$ during the experiment, and presented satisfactory production even in treatments without mineral fertilization. Biofertilizer could be an economically viable alternative to mitigate the effects of irrigation water salinity and may raise productivity in yellow passion fruit cultivation systems. 


\section{Resumen}

J.A.M. Nascimento, L.F. Cavalcante, Í.H.L. Cavalcante, W.E. Pereira, S.A.G. Dantas y S.A. S. Medeiros. 2016. Biofertilizante y fertilizante mineral en el crecimiento y la producción de maracuyá amarillo, regado con agua moderadamente salina. Cien. Inv. Agr. 43(2):253-262. El maracuyá amarillo, debido a la sensibilidad a la salinidad del suelo o del agua de riego, requiere la administración de estrategias de agua restrictivas para mitigar los efectos de las sales en las plantas regadas con agua salina, en niveles perjudiciales para el crecimiento y la producción de cultivos sensibles y moderadamente sensibles. En este sentido, se diseñó un experimento para evaluar los efectos de dosis de biofertilizante y mineral NPK fertilización sobre el crecimiento y rendimiento de fruta de maracuyá amarillo. Los tratamientos se dispusieron en un diseño de bloques al azar con tres repeticiones y 12 plantas por parcela, utilizando un diseño factorial $4 \times 2$, referidos a cuatro dosis de biofertilizantes bovina diluida con agua en las proporciones de $0 ; 33,3 ; 66,6$ y $100 \%$ en suelo sin y con el NPK. Se evaluaron las variables: diámetro del tallo, número ramas productivas en el inicio de la floración (160 días después del transplante de las plántulas), número de frutos por hectárea, peso promedio del fruto y productividad. La dosis máxima de bioferilizante combinado con la fertilización mineral NPK resultó en mayor diámetro del tallo, y el aumento de la productividad de las plantas, pero los resultados fueron superiores en plantas con fertilización mineral. En tratamientos sin NPK los valores de productividad aumentaron cerca de $24 \mathrm{t} \mathrm{ha}^{-1}$, con la dosis $60,65 \%$ del biofertilizante.

Palabras clave: Abono orgánico, salinidade, Passiflora edulis Sims.

\section{References}

Asik, B.B., M.A. Turan, H. Celik, and A.V. Katkat. 2009. Effects of humic substances on plant growth and mineral nutrients uptake of wheat (Triticum durum cv. Salihli) under conditions of salinity. Asian Journal Crop Science 1:87-95.

Cavalcante, L.F., F. Rodolfo Junior, J.R. SÁ, C.R.S. Curvelo, and E.F. Mesquita. 2007a. Influência da água salina e matéria orgânica no desempenho do maracujazeiro-amarelo e na salinidade do substrato. Irriga 12:505-518.

Cavalcante, L.F., G.D. Santos, F.A. Oliveira, Í.H.L. Cavalcante, S.C., Gondim, and M.Z.B. Cavalcante, 2007b. Crescimento e produção do maracujazeiro amarelo em solo de baixa fertilidade tratado com biofertilizantes líquidos. Revista Brasileira de Ciências Agrárias 2:15-19.

Cavalcante, L.F., G.F. Silva, H.R. Gheyi, T.J. Dias, J.C. Alves, and A.P.M. Costa. 2009. Crescimento de mudas de maracujazeiro amarelo em solo salino com esterco bovino líquido fermentado. Revista Brasileira Ciências Agrárias 4:414-420.
Dias, S.D., and F.F. Blanco. 2010. Efeitos dos sais no solo e na planta. p. 130-141. In: Gheyi, H.R., N. S. Dias, and C.F. Lacerda (eds). Manejo da salinidade na agricultura: Estudos básicos e aplicados. Instituto Nacional de Ciência e Tecnologia em Salinidade, Fortaleza, Brasil.

Dias, T.J., L.F. Cavalcante, J.L.O. Freire, J.A.M. Nascimento, M.Z. Beckmann-Cavalcante, and G.P. Santos. 2011. Qualidade química de frutos do maracujazeiro-amarelo em solo com biofertilizante irrigado com águas salinas. Revista Brasileira de Engenharia Agrícola e Ambiental 15:229-236.

Diniz, A.A., L.F. Cavalcante, A.M. Rebequi, J.C. Nunes, and M.A.S. Brehm. 2011. Esterco líquido bovino e ureia no crescimento e produção de biomassa do maracujazeiro amarelo. Revista Ciência Agronômica 42:597-604.

EMBRAPA. 2011. Manual de análises químicas de solos, plantas e fertilizantes. Embrapa, Brasília, Brasil. 230 pp.

EMBRAPA. 2013. Sistema Brasileiro de Classificação de Solos. Embrapa, Brasília, Brasil. $353 \mathrm{pp}$ 
Eyheraguibel, B., J. Silvestre, and P.Morard. 2008. Effects of humic substances derived from organic waste enhancement on the growth and mineral nutrition of maize. Bioresource Technology 99:4206-4212.

Freire, J.O., L.F. Cavalcante, A.M. Rebequi, T.J. DIAS, J.C. Nunes, and I.H.L. Cavalcante. 2010. Atributos qualitativos do maracujá amarelo produzido com água salina, biofertilizante e cobertura morta no solo. Revista Brasileira de Ciências Agrárias 5:102-110.

Hamdia, M.A., and M.A.K. Shaddad. 2010. Salt tolerance of crop plants. Journal of Stress Physiology \& Biochemistry 6:64-90.

IBGE. 2013. Produção agrícola municipal 2013. Series históricas, Brasília, Brasil. Available online at: http://www.sidra.ibge.gov.br/bda/pesquisas/ pam/default.asp?o=18\&i=P (Website accessed: August 1, 2015).

Khaled, H., and H.A. Fawy. 2011. Effect of different levels of humic acids on the nutrient content, plant growth, and soil properties under conditions of salinity. Soil \& Water Research 6:21-29.

Mahdi, S.S., G.I. Hassan, S.A. Samoon, H.A. Rather, S. A. Dar, and B. Zehra. 2010. Bio-fertilizers in organic agriculture. Journal of Phytology 10:4254.

Rodolfo Júnior, F., L.F. Cavalcante, and E.S. Buriti. 2008. Crescimento e produção do maracujazeiro amarelo em solo com biofertilizantes e adubação mineral com NPK. Revista Caatinga 21:134-145.

Rodrigues, A.C., L.F.Cavalcante, A.P. Oliveira, J.T. Sousa, and F. O. Mesquita, 2009. Produção e nutrição mineral do maracujazeiro amarelo em solo com biofertilizante supermagro e potássio. Revista Brasileira de Engenharia Agrícola e Ambiental 13:117-124.

Silva, M.A.P., G.R. Plácido, M. Caliari, B.S. Carvalho, R.M. Silva, C. Cagnin, M.S. Lima, R.M. Carmo, and R.C.F. Silva. 2015. Physical and chemical characteristics and instrumental color parameters of passion fruit. African Journal of Agricultural Research 10:1119-1126.

Soares, F.A.L., P.T. Carneiro., E.M. Gomes, H.R. Gheyi., and P.D. Fernandes. 2008. Crescimento e produção do maracujazeiro amarelo sob irrigação suplementar com águas salinas. Revista Brasileira de Ciências Agrárias 3:151-156.

Turan, M.A., B.B. Asik, A.V. Katkat, and H. Celik. 2011. The effects of soil-applied humic substances to the dry weight and mineral nutrient uptake of maize plants under soil-salinity conditions. Notulae Botanicae Horti Agrobotanici 39:171-177.

Viana, P.C., J.G.A. Lima, F.C.G. Alvino, J.R. Sousa Junior, E.C. Gomes, and K.C. Viana, 2012. Efeito da salinidade da água de irrigação na produção de maracujazeiro-amarelo. Agricultura Científica no Semiárido 8:45-50. 